\title{
Ser extranjero en Centroamérica. Génesis y evolución de las leyes de extranjería y migración en El Salvador: siglos XIX y XX
}

MOIsÉs GÓMEZ

Departamento de Filosofía

UCA, El Salvador.

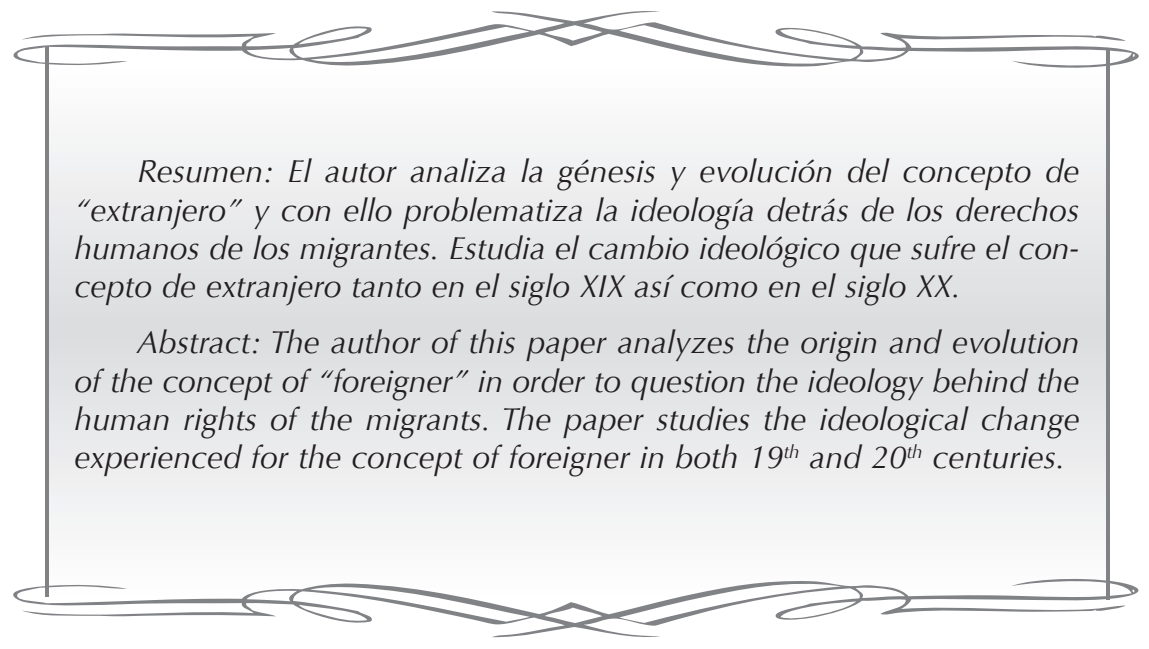

Candidato presidencial republicano, Mitt Romney:

"En una era de terrorismo, cárteles de droga, tráfico humano y bandas criminales, la presencia de millones de personas sin identificar en este país, supone un serio riesgo para la seguridad y soberanía de Estados Unidos" (Diario Digital La Pagina, 28-08-2012)

E n este ensayo me propongo indagar las causas por las cuales Centroamérica pasó de ser una región considerada santuario para el extranjero a ser una región xenofóbica. Me limitaré a estudiar el caso salvadoreño, lo cual me permitirá decir que más o menos igual sucedió en los distintos países de la región en el tema de la discriminación del extranjero. El discurso sobre "ser salvadoreño", "hondureño", "guatemalteco", "nicaragüen$\mathrm{se}^{\prime \prime}$ o "costarricense" indica una 
aversión mutua y recíproca entre centroamericanos. Esta aversión tiene su origen en la conceptualización del "otro" como el extranjero, y la cultura política latinoamericana, en sus versiones más tradicionalistas y autoritarias, ha exhibido con frecuencia una resistencia xenofóbica al otro-extranjero que amenaza la identidad nacional desde fuera y corroe la nación'.

Históricamente Centroamérica se ha imaginado como una unidad política, esto es, una sola nacionalidad. No siempre fue una preocupación, ni se dedicaron tantos recursos materiales y espirituales para defender la soberanía nacional de vecinos. En todo caso los recursos materiales y espirituales se orientaron para mantener la imaginaria unidad política ${ }^{2}$. Aunque la visión separatista y fragmentaria se impuso y cada república tomó su propio derrotero, el espíritu unionista centroamericanista se historiza en pequeñas situaciones políticas que no han sido muy bien comprendi- das. Un estudio y análisis profundo demostraría que nuestro pasado en materia de leyes de extranjería y de migración fue, por mucho, más coherente y práctico que las actuales legislaciones.

Debo aclarar que este análisis apenas es un acercamiento histórico-filosófico a nuestras leyes migratorias siguiendo el espíritu del método de historización de conceptos de Ignacio Ellacuría ${ }^{3}$.

Parto de la constatación de que, en parte, la realidad social se configura con leyes formalmente establecidas, por ello no es casual que hablemos del "Estado de derecho". La cuestión es cómo esas leyes se historizan, es decir, cómo y en qué medida se materializan en forma concreta en la vida de la sociedad en cada momento histórico.

La génesis y evolución del concepto de "extranjero" se limita a los siguientes documentos legales:

Constituciones de 1824 y 1886.

Leyes de extranjería de 1886 y 1986.

Leyes de migración de 1933 y 1958 (vigente en 2012)

Como una somera aproximación a nuestro tema diré que el Derecho de Extranjería ${ }^{4}$ es el que se ocupa de hacer la distinción entre el nacional y el extranjero. También es aquel que resuelve las relaciones entre el Estado y el sujeto extranjero ${ }^{5}$.

Para entender mejor el concepto jurídico recibimos el apoyo de la semántica: extranjero, forastero, 
es decir aquel extraño, de afuera (foras), distinto a los del grupo, a los que viven y se reúnen en el "foro". La etimología de este grupo de palabras es coincidente con la de forajido; foresta; en definitiva, nuestra etimología localiza al extranjero entre los conceptos de salvaje y enemigo. Este es el extranjero que toma en consideración el derecho de extranjería, el que desde fuera, y desde el peligro del exterior, toma contacto con la nación. Esta consideración de frontera hace que el derecho de extranjería se configure desde la óptica del conflicto ${ }^{6}$.

En la América Latina del siglo XIX el extranjero era generalmente bienvenido a la región gracias a la política que se resume en el lema de gobernar es poblar. Veamos dos casos ejemplares: México y Argentina.

Para el caso de México y de acuerdo con algunos referentes históricos, a comienzos del siglo XIX México era un país muy poco poblado. Esta situación se constituyó en una de las preocupaciones más importantes para el gobierno. Una de las soluciones en las que pensaron los primeros gobernantes del México independiente fue recurrir a la inmigración extranjera con la que, según su ideología, se poblarían las regiones deshabitadas del país. A raíz de la promoción de estas inmigraciones, desde 1828 se identifican diversas leyes y decretos, cuyo fin era facilitar el asentamiento de los extranjeros que llegaban a territorio mexicano, pero su concreción en proyecto fue con el presidente Manuel González en el período de 1880-1884. A pesar de esta política de poblamiento, la llegada de colonos no fue de la magnitud esperada por el gobierno. No obstante, durante el siglo XIX se asentaron en México familias francesas, belgas, italianas, rusas e inglesas. Aunque en un principio México recibió muchos asiáticos, sobre todo chinos y japoneses, gradualmente fue prohibiendo este flujo por considerarlo nocivo para la salud y la economía?.

En Argentina, Juan Bautista Alberdi diagnosticó las causas del subdesarrollo económico e identificó el sujeto del cambio capaz de superar esos escollos:

Nuestro hombre sudamericano debe ser el hombre formado para vencer al grande y agobiante enemigo de nuestro progreso: el desierto, el atraso material, la naturaleza bruta y primitiva de nuestro continente ${ }^{8}$.

Cuando Alberdi habla de "nuestro hombre sudamericano" que superara los desafíos al progreso ar- gentino no está hablando del típico indígena argentino, sino que se refiere al europeo inglés "importado": 
Es necesario fomentar en nuestro suelo la población anglosajona. Ella está identificada con el vapor, el comercio y la libertad, y no será imposible radicar estas cosas entre nosotros sin la cooperación activa de esa raza de progreso y de civilización 9 .

Para Alberdi difundir la idea de poblar su país con extranjeros europeos tenía que ver con una idealización de la raza blanca y por lo tanto implicaba un des- precio del indígena, el europeo era civilizado y el indígena un verdadero salvaje. Mejorar la raza argentina era vital para crear una nación civilizada:

¿Por qué razón he dicho que en Sud América, gobernar es poblar, y en qué sentido es esto una verdad incuestionable? -Porque poblar, repito, es instruir, educar, moralizar, mejorar la raza; es enriquecer, civilizar, fortalecer y afirmar la libertad del país, dándole la inteligencia y la costumbre de su propio gobierno y los medios de ejercerlo ${ }^{10}$.

Aunque Alberdi fue bastante duro con la discriminación de ciertos grupos de extranjeros (chinos, turcos y negros) en aras de ser con- secuente con su ideología liberal, admite que pese a todo lo malo que puede ser algún extranjero es mejor admitirlo antes que rechazarlo:

Pero tampoco hay que olvidar que el extranjero no debe ser excluido, por malo que sea. Si se admite el derecho de excluir al malo, viene enseguida la exclusión del bueno. En la libertad de la inmigración, como en la libertad de la prensa, la licencia es la sanción del derecho ${ }^{11}$.

Queda claro con esto que tanto en México como en Argentina la ideología dominante es la que fomenta la apertura hacia el extranjero.

\section{I-Historización del concepto de "extranjero" en el período de las reformas secularizantes"}

Artículo 12.- La República es un asilo sagrado para todo extranjero y la patria de todo el que quiera residir en su territorio $^{13}$.

A partir de 1871 la historiografía salvadoreña habla de un período de "reformas liberales" que culmina en el año de 1886; sólo en este úl- 
timo año se sancionaron leyes que significaron un enorme paso por parte del Estado salvadoreño en materia legal: Leyes de Amparo, para proteger los derechos individuales de los habitantes de la República; Ley de Estado de Sitio; Ley Reglamentaria de Elecciones; Ley de Imprenta y otras disposiciones varias. La Ley de Extranjería otorgaba derechos a los extranjeros, que incluían: invocar los tratados existentes entre El Salvador y su país y recurrir a la vía diplomática en caso de denegación de justicia y el beneficio de reciprocidad, conocidos como "derechos de extranjería", aún vigentes en la actualidad ${ }^{14}$.

Para hablar de "extranjero" en El Salvador hay que decir algo del fenómeno de las migraciones. A los flujos migratorios que configuraron la región mesoamericana en la época precolombina y que aún son poco conocidos, se suman inmigraciones de diversos grupos: la invasión española en el siglo XVI; la inmigración forzosa de miles de esclavos afro descendientes en el siglo XVII que siempre hallaron la manera de mezclarse con otras etnias ${ }^{15}$.

El Salvador del siglo XIX registra importantes grupos de inmigrantes chinos, belgas, alemanes, italianos, franceses y árabes (palestinos, libaneses, sirios), entre otros y sin embargo, de acuerdo a un estudio "el número de extranjeros nunca llegó a sobrepasar, como máximo, el de 500 individuos en el siglo pasado $^{\prime 16}$. En otro estudio consultado se establece datos estimados para los judíos en El Salvador: menos de 100 hasta antes de $1910^{17}$. Sobre el registro de datos de extranjeros y migraciones hay que aclarar que no fue hasta 1881 que nace la Oficina Central de Estadísticas, además, el primer Censo General de Población se levantó en 1882, por lo tanto, no hay datos fiables antes de la fecha mencionada ${ }^{18}$. Es interesante esta afirmación encontrada en el Anuario de 1937:

\begin{abstract}
Desde el año 1934 hasta 1937 ingresaron al país 95,668 personas y salieron en el mismo período 87,516 , quedando un excedente migratorio de 8,152 que aumenta la población de 1937 elevan ésta a 1, 673,500 habitantes. Debe hacerse constar que fue hasta 1934 que se llevó un control, completo del movimiento migratorio del país. Trabajo encomendado a la Oficina de Migración, creada con dicho objeto $^{19}$.
\end{abstract}

Podemos especular que en el siglo XIX la población "extranjera" residente temporal o permanente en El Salvador no pasó de 500 personas. Un cambio sustancial se registra en las primeras tres décadas del siglo XX ya que la población extranjera alcanzó la cifra de 8,152 
como saldo migratorio. Proporcionalmente en relación al total de la población la cantidad de extranjeros es aproximadamente $0.49 \%$, menos del $1 \%$ de la población total. Es insignificante estadísticamente pero de una importancia social no cuantificable.

\subsection{Significado del vocablo "extranjero" en la Centroamérica del siglo XIX}

Abordamos la primera Ley de Extranjería que fue elaborada por el Congreso salvadoreño de 1886 y publicada en el Diario Oficial del 1 de Octubre de 1886. De entrada vemos que de 1824 hasta 1885 no existió ninguna ley relativa a la regulación de los extranjeros, en parte porque se consideraba bien que la región fuera un santuario para todos los migrantes siempre y cuando tuvieran buena salud y recursos económicos para desarrollarse en el istmo.

Formalmente hablando la Constitución Federal de 1824 y la salvadoreña de 1886 e incluso la primera Ley de Extranjería de 1886 indican que el concepto "extranjero" no se aplica a los centroamericanos. Entonces nos preguntamos ¿a quienes se refiere?

La primera Ley de Extranjería se fundamentaba en el Título IV de la Constitución de $1886^{20}$; este apartado apenas tiene seis artículos, todos relacionados a los extranjeros y la forma legal de insertarse en nuestro país de manera civilizada. Nos interesa especialmente el último artículo porque allí se ordena la creación concreta de una ley de extranjería:

\section{Art.50.-Los extranjeros quedarán sujetos a una ley especial de extranjería.}

Nos preguntamos si eran los vecinos de los salvadoreños considerados como extranjeros y tene- mos que decir que no. La primera Ley de extranjería es muy clara al respecto:

Art. 56.-Los centro-americanos no serán considerados como extranjeros para los efectos de la presente ley.

Vemos que la ley en mención no fue pensada para aplicarse a los centroamericanos sino que más bien para aplicarse a cualquiera que no fuera de la región. Era una ley de extranjería para los no-centroamericanos.
El presidente Francisco Menéndez y el Congreso salvadoreño tenían claro que la región centroamericana era una sola nacionalidad y que el tan afamado principio de que somos un "asilo sagrado" para el extranjero de la Constitución Fe- 
deral de 1824 se refería a aquellos nacidos más allá del istmo.

Podemos afirmar que en la Constitución de 1886 y en la primera Ley de Extranjería no existía ningún problema que afectara a los centroamericanos relacionado con su derecho a movilizarse por toda la región ístmica. Hay que recordar que los territorios de la frustrada Republica Federal de Centro América incluía a los cinco países del istmo: Guatemala, Honduras, El Salvador, Nicaragua y Costa Rica.

De hecho, las Constituciones de la República y las Federales que rigieron efímeramente para
Centro América, contemplaron de manera tímida el ingreso de extranjeros y apenas reglamentaron, muy suscintamente, para lo corriente su permanencia dentro del territorio. Durante el siglo XIX y los primeros veinte años del siglo XX, solamente se estableció el principio general muy objetivista, por cierto, de que el Territorio Federal constituyera "un asilo sagrado" para el extranjero ${ }^{21}$. Existía por esa época un profundo espíritu de fraternidad y de unidad, no sólo ístmico, sino incluso latinoamericanista, tan fuerte es el sentimiento que de hecho la Constitución de $1886^{22}$ destaca como una disposición general:

Art. 151.-Siendo El Salvador una parte disgregada de la República de Centro-América, queda en capacidad de concurrir con todos, o con alguno de los Estados de ella, a la organización de un Gobierno Nacional cuando las circunstancias lo permitan y convenga así a sus intereses, lo mismo que a formar parte de la Gran Confederación Latino-Americana.

El hecho que los políticos liberales del último tercio del siglo XIX hayan promulgado una ley específica de extranjería, responde a la necesidad de formar un aparato jurídico que formara ciudadanía y ciudadanos pero sin descuidar la unidad regional.

Los ciudadanos deben vivir bajo la sombra de leyes y no sólo al arbitrio y capricho de los gobernantes. Ya no se concebía que existieran espacios sin legislar y era evidente la necesidad de leyes que se aplicaran a los nuevos flujos de migraciones.

En nuestro país, no es sino hasta el año de 1886 que se concretiza y amplía por medio de la Ley de Extranjería, las disposiciones constitucionales en torno a la situación del extranjero en el país, a fin de que éstos puedan adquirir derechos y contraer obligaciones aproximados a los que disfrutan los salvadoreños. 
Otra cuestión a la que responde la nueva legislación es la construcción de la "nación" salvadoreña. Si bien es cierto la nacionalidad es centroamericana cada Estado nacional está en la disyuntiva de crear su especificidad como "na- ción" y creo que una manera de hacerlo es construyendo sus "propias" legislaciones. La complejidad de esta disyuntiva entre el binomio "nacionalidad-nación" ha sido bien analizada por F. X. Guerra:

Los fundadores de los nuevos Estados, los constructores de las nuevas "naciones" fueron en su inmensa mayoría crioIlos y compartieron con su adversarios -americanos y peninsulares- todo lo que después, en otros lugares, servirá de fundamento a la "nacionalidad" un mismo origen ibérico, la misma lengua, la misma cultura, las mismas referencias políticas y administrativas. Sólo el lugar de nacimiento y las identidades regionales en formación los diferenciaban de los españoles de España. (...) Podríamos decir que el problema de la América hispana no es el de las diversas nacionalidades que van a llegar a formar un Estado, sino el problema de construir "naciones" separadas a partir de una misma "nacionalidad" hispánica. (...) ¿Sobre qué identidades colectivas apoyarse para fundar la nación? ?23. $^{23}$

Parte de la identidad colectiva de la nueva "nación" salvadoreña se construyó a partir de una madurez de la conciencia de los actores políticos y que fue objetivada en el aparato jurídico; los criollos hilvanaron un fino y delicado tejido legal que alcanzó su cenit en la Constitución de 1886.

La ley de puertas abiertas excluía en su artículo 14 cierto tipo de extranjeros a los que denominaba como "perniciosos": piratas, traficantes de esclavos, incendiarios, falsificadores de dinero y de documentos de identidad. En ningún punto se menciona discriminación por practicar alguna ideología (anar- quista o comunista, por ejemplo), mucho menos hace distinción étnica (árabes, asiáticos, africanos, etc.).

Los objetivos que pretende realizar la nueva ley de extranjería estaban relacionados directamente con el cumplimiento del mandato constitucional (Art. 50 de la Constitución de 1886). Además, uno podría especular en esta lógica: en primer lugar, nuestro país no escapó de la ideología liberal que pensaba que gobernar es poblar, tal como se creía en México y en Argentina; se trataba de poblar con gente industriosa y respetuosa de las leyes, la idea era abrir las puertas de la nación para atraer más 
que todo gente inglesa y francesa. También se cumplía con el objetivo de la "conservación de las buenas relaciones internacionales", dándole buen trato a los extranjeros, eso se consideraba una forma civilizada de asegurar la paz y el bien común de la República. En tercer lugar, leyes de extranjería y otras secundarias estaban en consonancia con la idea de formar un nuevo tipo de ser ciudadano, tal como lo destaca Julián González Torres:

El ciudadano moderno nace íntimamente vinculado al concepto de nación. Uno de los requisitos indispensables para gozar de la ciudadanía sería la nacionalidad. En el mundo moderno se es ciudadano de una nación (estadounidense, francesa, española, salvadoreña, etc.). Parafraseando a Benedict Anderson, se inventa una comunidad de iguales: la comunidad es la nación; los iguales son los ciudadanos ${ }^{24}$.

Se trata de formar ciudadanos que cumplen las leyes basadas en la razón y que ordenan la vida de una nación de "iguales" esto es, que están todos bajo el gobierno de las leyes sin distinción de su origen social o por su nacimiento.

Los beneficiados directos con esta ley era pues, toda la región centroamericana y a sus habitantes ya que garantizaba el libre movimiento de los ciudadanos entre los cinco países, garantizaba el derecho al trabajo, cualquiera podía optar a trabajar y ganarse la vida en cualquier país del área, residir y optar por cargos políticos incluso. Todo ello sin mayores problemas.

Era, además, una ley hospitalaria con los extranjeros pues recogía los artículos 42 al 44 de la Constitución de 1886, mismos que ofrecían facilidades para conseguir la naturalización, ésta se podía conseguir de mu- chas maneras: por medio del gobernador de la zona al que le bastaba ver buena conducta en el extranjero y que diera cuenta de haber residido por dos años al menos; por carta extendida por diputados; al aceptar un trabajo público (que no fuera profesor o militar). Desde el punto de vista de los derechos humanos de los migrantes, esta legislación era muy buena para las personas que por una u otra razón debían venir al territorio salvadoreño.

\subsection{La realidad concreta a la que se aplica el concepto}

La realidad concreta a la que se aplica el concepto formal de "extranjero" no está "dentro" de la región sino fuera de ella. Es importante resaltar aquí el "desde" dónde se conceptualiza al "Otro", o lo que es igual, identificar la ideología vigente y dominante que se da a la tarea de conceptualizar al Otro. 
Podemos afirmar que el "desde" es una región que se considera "una" Centroamérica políticamente hablando, domina la ideología de la unidad política regional. Por ejemplo, Valdés Valle habla del "factor masónico": al revisar toda la publicación de la nueva Ley de Extranjería en el Diario Oficial del 1 de octubre de 1886, al final aparecen los nombres de los congresistas que realizaron la ley: Domingo Jiménez (liberal y masón); Máximo Mancía (liberal y masón) y J. Guandique (ultramontano). Valdés Valle en su estudio doctoral ya citado muestra la influencia de lo que llama el "factor masón" en todas las leyes emitidas en el último tercio del siglo XIX. No es raro que también la ley de extranjería lleve la impronta de la libertad de movimiento para todos los centroamericanos sin ninguna restricción. Valdés Valle destaca que uno de los ideales masónicos en Centroamérica era lograr la unión:

No obstante el discurso que ofreció Lorenzo Montúfar, en su calidad de Ministro de Estado masónico, al instalarse el 12 de Febrero de 1871 el Gran Oriente Centro-Americano en San José, Costa Rica, ya anunciaba con claridad dos de los sueños esenciales que desde entonces guiarán las acciones "políticas" de los masones centroamericanos en sus relaciones con el "mundo profano" o existente fuera de la Logia: mostrar que sí es posible reconstruir la unión política de Centro América ${ }^{25}$.

Es desde este horizonte donde hay que situar la Constitución de 1886 y la primera Ley de Extranjería del mismo año. Corresponde a una visión ideológica que cree en la unidad de la región y por lo tanto impregna de esa ideología las leyes sean cuales sean.

Valdés Valle también hace hincapié sobre las luchas y divisiones ideológicas entre los mismos liberales, ello nos indica lo difícil de Ilevar adelante el proyecto unionista centroamericano desde las distintas constituciones salvadoreñas. De acuerdo a este autor, la fracción liberal masónica se dividió entre ella misma cuando se discutió el todavía proyecto de ley constitucional de 1886: una parte de la fracción exigía que la carta magna reflejara generosamente el ideal liberal del unionismo centroamericano; mientras que la contrapartida, también liberales masones, eran de la idea de una nueva constitución que restringiera y limitara el ejercicio de la ciudadanía y derechos políticos a los "nacidos" en El Salvador; la siguiente es una cita larga que nos ayudará a fortalecer teóricamente este apartado, y poder con esta información problematizar la constitu- 
ción de 1886; en la cita se cuestiona los artículos 40, 41, 58, 82 y 85, que implican limitaciones políticas a los ciudadanos centroamericanos:

Llegamos, sin duda, a los artículos que generaron mayor malestar entre los medios impresos afines al Presidente Menéndez: el marcado "localismo" que caracterizó a la Constituyente del 85. Aunque cada uno de estos artículos abordan diferentes aspectos, todos ellos coinciden en una sola cosa: limitar los privilegios políticos a los ciudadanos de las otras Repúblicas centroamericanas, privilegios o derechos de optar a cargos públicos como Diputados, Ministros de Estado, y hasta Vice-Presidente y Presidente de la República. Para introducirnos a esta problemática, voy a traer a colación los comentarios que hicieron los Agricultores de Pasaquina en sus Observaciones al Proyecto de Constitución; en él se explica con toda claridad el inconveniente que tenían estos artículos: "Pero donde mas resalta el espíritu de localismo, por no decir otra cosa, es en los artículo 79 y 82 del proyecto al establecer que la Presidencia ó Vice Presidencia de la República, lo mismo que los Ministros de Estado, solo deben recaer y ser ejercidos por los salvadoreños de nacimiento. Esto rompe las tradiciones del hospitalario suelo salvadoreño: empaña sus generosas tendencias de unificación de la disgregada familia centroamericana, y se aparta en absoluto de la conducta de los demás Estados» 2627.

Analizando la cita de más arriba entiendo que cuando los agricultores se refieren al "localismo" de la Constitución de 1885 se comprende que es un defecto que tiene la carta magna. Con el vocablo "localismo" se refieren a la tendencia ideológica a limitar, vía leyes restrictivas y cerradas, los derechos políticos a los no nacidos en territorio salvadoreño. Ese localismo ya va perfilando, jurídicamente, el concepto de extranjero y sus limitantes en cuanto a derechos que puede exigir un extranjero en nuestro país.
A criterio de Valdés Valle, ese localismo también se filtra a la nueva constitución de 1886 . Por nuestra parte pensamos que aunque restringe a los centroamericanos no nacidos en El Salvador el acceso a ciertos cargos políticos, todavía así no los declara como "extranjeros" peligrosos, tal como ocurre hoy en día, que se considera al extranjero como una amenaza.

Podríamos preguntarnos si el "localismo" que se criticó de la Constitución de 1886 es ya un sín- 
toma del nacionalismo que aparece en el siglo XX, pero inmediatamente hay que responder que no. Hay que decir tajantemente que el nacionalismo surge en nuestro país a principios del siglo XX principalmente por el fomento del ceremonial público y la producción masiva de monumentos y en menor medida por medio de la educación primaria tal como lo enfatiza Carlos Gregorio López Bernal $^{28}$.

Cuando afirmo que el "localismo" del siglo XIX no puede ser considerado como "posibilitante" del futuro nacionalismo del siglo XX, lo digo a partir de Ellacuría mismo, para quién "el pasado, como realidad, ya-no-es, pero sí "son" las posibilidades que ha otorgado; el pasado continúa como posibilitación" 29 . Desde nuestro punto de vista aquel "localismo" quería construir una "nación" con una identidad jurídica propia y no era marcadamente excluyente de los centroamericanos como lo será el "nacionalismo" del siglo XX. Por ejemplo el "localismo" del siglo XIX creó y permitió la Ley de Extranjería de 1886, que es completamente unionista y centroamericanista, aunque con ciertas restricciones del orden de los derechos políticos; por su parte la tradición inventada del "nacionalismo" ideologizado del siglo XX creó la Ley de Migración en 1933 que es, desde todo punto de vista bastante alejada del espíritu de la constitución de 1886 vigente en ese tiempo, y sobre todo es anti-centroamericanista.
Para nuestro interés lo importante es el resultado obtenido por aquellos migrantes (extranjeros), una región más comprensiva de la necesidad o mejor dicho, más respetuosa de lo que Ilamamos el derecho a migrar, el derecho a vivir donde uno no ha nacido. La ley de 1886 facilitaba la inserción digna de los extranjeros en la región y, además, fomentaba la armonía social entre los naturales del istmo.

\subsection{Condiciones que permitieron la historización del concepto, tal como ocurrió en el siglo XIX}

Las reformas liberales o secularizantes tenían bien claro construir un El Salvador con un estado de derecho, que en términos de migración y extranjería fue, desde mi punto de vista, muy exitoso. Ciertamente los políticos y legisladores se cuidaron de hacer leyes que se apegaran a la realidad de la ideología colectiva y dominante hacia la unidad centroamericana. La ley de extranjería más que impedir fomentaba la libre movilidad entre los nacionales de los cinco Estados. La xenofobia hacia el no nacido en la región o peor, entre centroamericanos era inconcebible y jamás se pensó en legislar para reforzar los miedos a lo extraño, al Otro, ya sea por razones étnicas o culturales. Mucho menos se hicieron leyes de extranjería como parte de políticas de seguridad nacional o para cumplir el principio de soberanía na- 
cional en menoscabo de derechos fundamentales como el derecho a la libre movilización tal como ocurre hoy en día.

Puedo afirmar que en la legislación relativa a los extranjeros en el siglo XIX se refiere jurídicamente a ellos como personas, mientras que las nuevas leyes del siglo XX relativas a los extranjeros más bien buscan construir la "no-persona" por cuanto se hacen con miras a excluir de algunos derechos a los extranjeros en nuestro territorio salvadoreño. Veamos el caso de la primera ley de migración que fue promulgada en 1933 como un caso claro de construcción jurídica de la no-persona ${ }^{30}$.

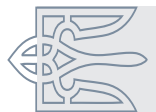

\section{El concepto de "extranjero" en la Ley de Migración de 1933}

Para la década de los treinta del siglo XX el concepto de "extranjero" tenía otras connotaciones que no tenía en el siglo XIX. El extranjero era considerado como la no-persona. El nacionalismo (no el "localismo" señalado más arriba) se plasmó en La Ley de Migración de 1933, que consideraba extranjero a todo aquel que caía bajo el capítulo III "Restricciones y limitaciones a la inmigración" que decía en su artículo 25: "Se prohíbe la entrada al país, a los extranjeros comprendidos en uno o más de los casos siguientes: a los de raza negra; a los malayos y a los gitanos, conocidos también en el país con el nombre de 'húngaros'". Y el artículo 26 continuaba: "No se permitirá asimismo el ingreso al país de nuevos inmigrantes originarios de Arabia, Líbano, Siria, Palestina o Turquía, generalmente conocidos con el nombre de turcos".

La ley surge en un contexto político difícil ya que un año antes ocurren los graves sucesos de 1932 donde fueron reprimidos y muertos muchos miles de campesinos en su mayoría indígenas que se levantaron contra las élites dominantes y donde se creía que todo fue orquestado por organizaciones comunistas:

Así que en 1930 y 1931, la población rural del occidente de El Salvador estaba en una situación de crisis aguda, y comenzaron a movilizarse en respuesta a ello. Existe un gran debate en cuanto a si el Partido Comunista Salvadoreño y otras organizaciones hermanas, el Socorro Rojo Internacional o la Federación Regional de Trabajadores Salvadoreños, tuvieron responsabilidad en la organización del levantamiento. No hay duda de que algunos miembros de estas organizaciones querían desesperadamente organizar a los trabajadores del café y liderar una insurrección ${ }^{31}$. 
Suena plausible concluir que la amenaza de la ideología comunista que los mal llamados turcos podrían portar era mejor evitarla, más aun aquellos extranjeros podrían ser militantes comunistas y por tanto a los legisladores salvadoreños de 1933 les resultó mejor prohibir su presencia e ingreso al territorio salvadoreño.

Cualquier vecino de los salvadoreños se catalogó y se consideró como extranjero. Incluso los mismos salvadoreños son tratados como si fueran extraños a la nación:

Art. 12.-Las autoridades de migración no concederán permiso para entrar o salir del territorio de la República si el interesado no exhibe previamente su Cédula de Vecindad o su tarjeta Individual de Identificación en su caso.

En esta ley de migración si los salvadoreños querían salir del país debían identificarse con su cédula de vecindad o de lo contrario no podían salir. Esta ley de migración no operaba con el principio de la presunción de "inocencia", todo lo contrario, del salvadoreño común se "presumía" "culpabilidad" anticipada, ya que las autoridades asumían que tenía deudas con el Fisco o con el Municipio y por esta razón el ciudadano debía mostrar a la autoridad migratoria que no era así y que estaba "solvente" para moverse libremente ${ }^{32}$. Para salir del país el ciudadano tenía que demostrar su inocencia, es decir la carga de la prueba recaía sobre el supuesto imputado.

Me pregunto: ¿por qué hacer una ley de migración que se aleja del espíritu de la Constitución de 1886? Para tratar de comprender esta ley en su contexto político propongo analizarla a la luz de dos problemas fundamentales que vive el país a inicios del siglo XX: el co- munismo y los brotes de violencia social. Ambos se correlacionan en un solo evento que marcaría nuestro siglo XX: la masacre de 1932. La nueva ley es una barrera anticomunista (prohibiendo ideologías anarquistas: comunismo, socialismo) y al mismo tiempo un mecanismo de higiene social (prohibiendo la entrada de ciertos grupos raciales etiquetados como no aptos para contribuir al progreso social, p.e. afrocaribeños, chinos, etc.). De hecho ambas se complementan.

El problema de los "turcos" salvadoreños que al final resultaron ser realmente judíos árabes, esto es, de lengua y cultura "árabe", entre los cuales había algunos de fe y religión "judía" 33 no se creó aquí en la región centroamericana sino que nos vino de fuera. Las primeras tres décadas del siglo XX Europa vive un tiempo anti-utópico, los campesinos rusos han derrumbado el régimen zarista y los comunistas leninistas toman las riendas del estado ruso. 
Lejos de Rusia, en la Alemania que vio nacer a Marx, está ocurriendo una revolución sin hacer mucho ruido. Hitler va en ascenso con su ideología nacional-socialista. Para 1933, el partido hitleriano de corte eminentemente anti-judío se hace con el poder del Reichstag (Asamblea legislativa alemana).

En la Europa de inicios del siglo XX se construyó una conceptualización del judío "comunista" y a la vez como "plaga" ${ }^{34}$. Hitler combinó ambos argumentos para terminar en el genocidio nazi ya conocido.

Según Olivier Prud'homme en el lapso de 1886 a 1918 las representaciones o relatos sobre los turcos que los salvadoreños tenían eran distorsionadas, provenían de notas aparecidas en el Diario Oficial y en el Diario del Salvador ${ }^{35}$ que a su vez los retomaban de las salas de redacción de periódicos ubicados en Londres o París. Inglaterra, Francia, el Imperio austro-húngaro y Rusia tenían fuertes intereses económicos con el Imperio Otomano y usaban cualquier excusa para hacer ver mal al gobierno otomano. Obviamente, se pusieron de lado de los judíos frente a la supuesta agresión musulmana $^{36}$. La percepción de los salva- doreños era que los turcos y judíos venían "huyendo" de la maldad del gobierno otomano, que entre otras cosas se dedicó a "perseguir" a los cristianos por su fe. Antes de 1933 estos "refugiados" — por el simple hecho de tener una religión distinta de la religión oficial musulmana-y bajo el lema de que Centroamérica era un "asilo sagrado" para el extranjero eran recibidos cordialmente.

Hasta aquí el elemento "extranjero" usualmente se consideraba "positivo" para la nación, para el mestizaje y para la economía. Así como los turcos y árabes otros grupos de comerciantes extranjeros (usualmente "buhoneros") se unían a las élites locales y eran asimilados por naturalización a nuestro ordenamiento social y además establecían redes migrantes entre un estado y otro $^{37}$.

A falta de los europeos que nunca vinieron tal como esperaban los gobernantes salvadoreños y centroamericanos, Ilegaron los "turcos". A partir de la masacre de 1932 la percepción positiva de los supuestos "turcos" cambia radicalmente en el período entreguerras tal como lo señala Wilson:

La república se vio obligada durante el período entre guerras (1919-1941) a enfrentar la influencia de los inmigrantes extranjeros, la competencia de las repúblicas vecinas y la dependencia en los mercados y proveedores extranjeros. En términos de su política interior, tuvo que proteger los intereses de cada una de las principales agrupaciones sociales 
(...), el notorio fracaso del movimiento unionista de 1921 dejaron en evidencia que las bases históricas de la unión del istmo se estaban derrumbando. Para 1930 El Salvador ya no creía que fuera deseable o posible el depender de una eventual confederación para asegurar su futuro ${ }^{38}$.

Justamente en la Ley de Migración vemos que el "Considerando" de la ley reza "que para la mejor defensa y protección de la sociedad y del Estado así como de los intereses nacionales se dictan las nuevas disposiciones que afectan a toda clase de personas ${ }^{39}$.

La ley es para radicalizar las medidas de seguridad frente a los flujos de migraciones que luego de la apertura del Canal de Panamá se hacen más fáciles, hay que agregar además las nuevas formas de transporte a partir de la invención de autos y barcos con máquinas de vapor más rápidos. También hay notable mejoramiento de caminos y calles que facilitan el tránsito por el istmo.

¿Se utilizó la ley de migración como una barrera anticomunista? Todo parece indicar que sí, veamos cómo. El historiador López Bernal relata que cuando las autoridades buscaban una explicación para los sucesos de 1932 terminaban por concluir que sólo pudo ocurrir si había una manipulación mental del indio, inmediatamente se sospechaba de la presencia de "extranjeros" que se dedicaron a agitar a los campesinos del occidente del país:

No obstante que el problema era muy complejo, la explicación fue muy sencilla: en el país no había lugar para la "lucha de clases" porque no existía explotación, ni injusticia, ni falta de libertad. Claro que había algunos problemas, sobre todo por la caída de los precios del café, pero no hubiesen bastado para provocar un levantamiento de tal magnitud. Por otra parte, los indios no eran malvados por naturaleza; habían llegado a cometer tan "brutales excesos" (asesinatos, robos, violaciones, mutilaciones, etc.) porque los "agitadores comunistas" (invariablemente extranjeros) les envenenaron el alma con la prédica del odio de clases ${ }^{40}$.

Los decisores o tomadores de acción impidieron por ley la entrada al país de más de aquellos "extranjeros" en parte responsables del levantamiento indígena, al introducir una ideología anarquista como era el comunismo; derivado de esto es que el inciso $9^{\circ}$ del artículo 25 de la ley de migración de 1933 puntualizaba que se prohíbe la entrada al territorio nacional: 
$9^{\circ}$. A los anarquistas, terroristas, o a los que sean miembros o afiliados de organizaciones, asociaciones o grupos que propaguen doctrinas contrarias a la familia, a la propiedad privada, $o$ al régimen social y económico establecidos en El Salvador.

Desde mi punto de vista, queda claro que la ley de migración sirvió como parte de la defensa del estado salvadoreño ante amenazas de ideologías como el comunismo y en ese afán desconoció que la Constitución de 1886 no restringía la permanencia en territorio salva- doreño a ningún extranjero por su ideología. Respecto del higienismo social en la ley de migración, un claro objetivo de la ley de migración, que no se dice pero que manifiestamente está operativizado, tiene que ver con el higienismo social:

El higienismo social en El Salvador asimiló el ideario de la policía médica en su vertiente europea de finales del siglo XVIII y principios del XIX. Una de las características de este proyecto higienista social fue la asimilación de los conceptos del positivismo de Augusto Comte (1798-1857), y de algunas de sus expresiones, como lo fueron el darwinismo social de Herbert Spencer (1820-1903), y la corriente de la Antropología Criminal impulsada por Cesare Lombroso (1835-1909). Fusión del modelo de policía médica con este entorno positivista dio paso al concepto de higienismo social, el cual parece haber traducido, por parte de los sectores gobernantes, la preocupación por encontrar una metodología para ejercer la defensa social ante las amenazas de lo que, para esa época, el aporte de las ciencias médico psiquiátricas había concretizado en la figura de las clases peligrosas. Dentro de ellas se configuró al degenerado biológico y moral, propenso a la delincuencia y la criminalidad, enemigo del orden y el progreso. Para ellos había que desarrollar estrategias de control, corrección, eliminación o asimilación. Lo anterior fue asumido por los sectores dominantes de la época como un referente de análisis, no solo para entender la dinámica que producía y mantenía la enfermedad individual y del colectivo social, sino mayormente para implementar los mecanismos de corrección y prevención al interior de la sociedad ${ }^{41}$.

La ley de migración se puede considerar como parte de esos "mecanismos de corrección y prevención al interior de la sociedad" 
para identificar "las clases peligrosas" tal como afirma Oliva Mancía. Ciertamente este higienismo social que explica, al menos en parte, la ley de migración de 1933 no es de corte "antiindígena" sino estrictamente anticomunista y antijudío porque se asoció al judío con la ideología comunista, a la que se achacaba, desde el gobierno, ser la responsable del levantamiento indígena del 32. Los militares al mando de las tropas que restablecieron el "orden" social tras los eventos de enero de 1932 se referían a los indios como proletarios y no como simples indígenas. Según López Bernal, los militares de la época se referían a los indígenas como "bolcheviques" y como miembros del "ejército rojo"42.

Una década más tarde, en 1942 Rodolfo Barón Castro insistía en la defensa y en crear mecanismos de control, no tanto por puro higienismo social, sino por mor de la defensa de la nacionalidad, que para nosotros refleja un falso entendimiento de cómo querían construir naciones independientes a partir de una misma nacionalidad:

No se trata de eliminar a este o aquel inmigrante porque pertenezca a tal o cual raza, sino porque la nacionalidad recaba el concurso, en primerísimo lugar, de aquellos elementos que por su fácil asimilación pueden convertirse cuanto antes en factor progresivo, rechazando a aquellos que, independientemente de sus cualidades intrínsecas, sean reacios a su inclusión en el cuerpo nacional, convirtiéndose, por ende, en factores retardatarios. Este estricto sentido defensivo, aplicado a nacionalidades en pleno período de formación, no puede ser más legítimo ${ }^{43}$.

Barón Castro en la cita de arriba da a entender que la razón de "eliminar" (esto es higienismo social) o no dejar entrar a ciertas razas y etnias, se debe no tanto por rechazar o eliminar razas en sí mismas; la razón es "ideológica-económica" porque "la nacionalidad" en un estado moderno se asocia al progreso y a la industria, y, en definitiva, al desarrollo económico. En este sentido peyorativo y discriminador se creía que los judíos y los negros no podían aportar nada para el desarrollo de una nación. ¿Qué diría hoy Barón Castro que Barack Obama sea el presidente de los Estados Unidos?

Definitivamente esta ley de migración no beneficiaba a la población salvadoreña ni a la centroamericana que vio totalmente restringida su libertad de movimiento. Seguramente benefició a una pequeña élite y/o clase política y económica que por medio de la colonización de la política impu- 
so medidas proteccionistas de sus inversiones y sus propios intereses. El abanderado de esta élite fue el general Maximiliano Hernández Martínez. Este es un personaje difícil de comprender por su vida tan polémica.

Las investigaciones muestran que era masón, teósofo ${ }^{44}$ muy vinculado a las redes de intelectuales de El Salvador y de la región; un hombre liberal, anti racista y unionista y que, según el discurso oficial, apreciaba a los indígenas porque creía en la fraternidad entre todos los hombres. Entonces ¿cómo explicamos todos los eventos de violación de los derechos humanos que ocurrieron en su dictadura? ${ }^{45}$ ¿Quiénes fueron los que se escudaron detrás del General Martínez? Esta investigación no alcanza a identificarlos pero un estudio de más largo aliento podría arrojar datos novedosos.

En 1892 Santiago Barberena escribía lo siguiente referido a los extranjeros y cómo eran acogidos:

El pueblo salvadoreño de suyo bondadoso, y bastante ilustrado, ya es esencialmente tolerante en los límites que permiten las buenas costumbres y las conveniencias sociales. Protestantes, judíos, mahometanos, llegan cada día a nuestras playas y nadie se inquieta ni les preguntan por la religión que profesan. El extranjero encuentra aquí franca y benévola acogida. A El Salvador han llegado inmigrantes de todos los países siendo las colonias extranjeras más numerosas la alemana, la española, la norte-americana, la francesa, la italiana, la inglesa y la belga. Hay también hispanoamericanos y unos cuantos asiáticos ${ }^{46}$.

La Constitución de 1886 estuvo vigente (aunque con reformas superficiales) hasta agosto de 1950, cuando se hizo una nueva constitución nacional que abandona los principios del liberalismo decimonónico y adopta principios "sociales"; esto quiere decir que la nueva Constitución enfatiza más que los derechos civiles y políticos que, según los legisladores, ya estaban bien asentados, la satisfacción de necesidades económicas y culturales que no habían sido atendidas adecuadamente. En parte esta nueva ley recoge las orientaciones de la Declaración Universal de los Derechos Humanos adoptada por la Naciones Unidas en 1948.

Es claro que la orientación constitucional de la década de los años cincuentas del siglo XX cambia radicalmente; un dato importante que reafirma este giro fue el hecho que el 14 de octubre de 1951 los ministros de Relaciones Exteriores del istmo firmaban la 
Ilamada Carta de San Salvador ${ }^{47}$, estableciendo la creación de la Organización de Estados Centroamericanos (ODECA); esta misma evolucionó hacia 1991 al establecimiento del Sistema de la Integración Centroamericana (SICA), el Ilamado "sucesor" de la ODECA, teniendo también su sede en El Salvador, con el propósito de promover una mayor integración y cooperación entre nuestros países. Esto significó que la integración política cedió paso a la integración económica, tal como lo señala este texto fundacional:

Artículo 1. Costa Rica, Nicaragua, Honduras, El Salvador y Guatemala son una comunidad económico-política que aspira a la integración de Centroamérica. Con tal propósito se ha constituido la Organización de Estados Centroamericanos $(O D E C A)^{48}$.

En 1991 este artículo 1 lo retoma integro el Protocolo de Tegucigalpa que funda el SICA:

Artículo 1.- Costa Rica, El Salvador, Guatemala, Honduras, Nicaragua y Panamá son una comunidad económico-política que aspira a la integración de Centroamérica. Con tal propósito se constituye el SISTEMA DE LA INTEGRACION CENTROAMERICANA, integrado por los Estados Miembros originales de ODECA y por Panamá, que se incorpora como Estado Miembro ${ }^{49}$.

Más adelante se enfatiza que debe ser un sistema de integración "armónico" aunque siempre a par- tir del desarrollo económico como locomotora que empuja hacia la unidad regional:

Artículo 3, Literal $h$

Promover, en forma armónica y equilibrada, el desarrollo sostenido económico, social, cultural y político de los Estados miembros y de la región en su conjunto ${ }^{50}$.

Lo dicho anteriormente, la nueva comunidad primero es económica y luego todo lo demás, siendo lo político la última opción. Entonces, resultado de examinar todos estos cambios, comprobamos que también la misma realidad social es otra y es eso lo que reflejan en materia de extranjería y migraciones las nuevas legislaciones. Teniendo todos estos elementos en consideración y de cara al método de historización que empleamos, Ellacuría nos advertiría para ser considerado que: 
Lo importante en el proceso de historización no es el logro alcanzado en un momento determinado, sino la orientación del proceso. Pero no su orientación ideal, sino su orientación real ${ }^{51}$.

Justamente examinar la orientación del proceso, tal como habla Ellacuría, es lo que nos lleva a nuestro siguiente paso, que consiste en analizar y comprender históricamente la aparición de la Ley de Migración de 1958 y la de Extranjería de 1986.

\section{El extranjero en la Ley de Migración de 1958 y en la Ley de Extranjería de 1986 (ambas vigentes)}

La ley de migración surge en el marco de la unidad económica y política de Centroamérica y retoma los nuevos pactos unionistas de corte economicista de la región.

Los especialistas y cuantificadores de las migraciones coinciden que hasta fines de la década de 1970, el fenómeno de las migraciones fue básicamente intrarregional, los flujos de población se limitaban a traslados internos y movimientos internacionales transfronterizos entre las áreas rurales de los países vecinos.

Los movimientos migratorios en el país tienen su auge en el período entre 1970 y 1980, época de efervescencia del conflicto armado y donde el número de personas que se dirigieron hacia otros países de América se duplica. El Salvador es el que más aumenta su cantidad de emigrantes en la subregión, seguido de Guatemala y Panamá. Para 1990, más de medio millón de salvadoreños se encontraban en el extranjero, cifra 3 veces superior a la de 1980, producto principalmente del conflicto armado en el país.Cabe señalar que el desplazamiento de la población interna también se ve afectado. En ese momento, El Salvador destaca como el principal país expulsor, responsable del $40 \%$ del total de la emigración de la subregión, que en un $80 \%$ se dirige a los Estados Unidos ${ }^{52}$. Para el año 2000 el Censo de los EE.UU reportó 655 mil salvadoreños en su territorio. ${ }^{53}$

El Salvador se ha "extranjerizado" en el sentido que gran parte de su población está fuera de su país. Cada salvadoreño es un "extranjero" en potencia.

En la ley de migración de 1958, el extranjero es esencialmente un turista:

Artículo 6.- Son turistas las personas que ingresen al país con fines recreativos, de salud, familiares, religiosos, deportivos, culturales y otros semejantes; o en tránsito, y perma- 
nezcan en el territorio nacional por más de cuarenta y ocho horas, hasta NOVENTA DIAS, o por otro período igual; pero no podrán dedicarse a ningún trabajo.

Sobre la Ley de Extranjería de 1986 que derogó la ley hecha en el siglo XIX, debo resaltar un cambio radical. Si en la primera ley de extranjería del siglo XIX no se consideraba extranjeros a los centroamericanos, la nueva ley sí los considera de esa manera hasta que no manifiesten su deseo de naturalizarse ante la autoridad respectiva:

Art. 1.- Son extranjeros los nacidos fuera del territorio nacional, originarios de otros Estados que no han obtenido la calidad de salvadoreños por naturalización y los originarios de los demás Estados que formaron la República Federal de Centro América, que teniendo su domicilio en El Salvador, no han manifestado ante la autoridad competente, su voluntad de ser salvadoreños por nacimiento

Tanto la ley de migración como la ley de extranjería vigentes hacen un uso ideologizado del concepto de extranjero.

Detrás de esta declaración formal, hay una mentalidad perversa de corte economicista, pues en nuestro país asumimos que el emigrante es el salvadoreño (uno de nosotros) que sale del país para trabajar en el extranjero. Así vemos que hay salvadoreños por todo el mundo; nos jactamos de lo laborioso que somos y de cómo nos insertamos en la vida económica de otros países, sean estos desarrollados o subdesarrollados. El estado salvadoreño vela por este salvadoreño cuando está en calidad de extranjero y de alguna manera exige que a nuestros compatriotas se les trate con dignidad donde se encuentren.
Inmigrante es un concepto ambiguo. En primer lugar, puede ser el extranjero que viene al país de visita. A este inmigrante se le aplica el concepto de turista en tanto y en cuanto es extranjero. Como tal, tiene todos los derechos de extranjero que gozan los salvadoreños menos la nacionalidad, pero para ello debe traer dinero, ser rico o inversionista. Sólo de esta forma tendrá derecho a gozar de la protección del Estado salvadoreño. Desde otro punto de vista, el inmigrante es aquel extranjero (el trabajador migratorio) que viene a nuestro país con miras a establecerse y con intenciones de apropiarse de aquello que creemos nos pertenece (plazas de trabajo ante todo).

Dicho de otra manera, el emigrante es uno de nosotros que se 
sacrifica yéndose del país, es un honrado trabajador que no duda en dejar su terruño para ir en busca del trabajo en el extranjero con el fin de mejorar su propia condición de vida y la de los suyos, por medio del envío de remesas económicas.

Muy al contrario, pensamos que el inmigrante es el "Otro" es un extranjero que o dos cosas: o trae dinero y es turista, o es un intruso que viene de fuera a quitarnos algo de lo que tenemos; por ejemplo, los nicaragüenses, con presencia fuerte en San Miguel y Usulután, ocupan las plazas de trabajo en los ingenios azucareros de la zona ${ }^{54}$. Los nicaragüenses desplazan a los salvadoreños en la corta de la caña y café; las mujeres nicaragüenses ahora son, cada vez más, contratadas como "domésticas" o empleadas en labores del hogar, desplazando a "nuestras" mujeres salvadoreñas. Las mujeres nicaragüenses además trabajan en comedores, pequeños negocios o comercios en los mercados locales. Son extranjeros, son trabajadores, no son turistas y están violando las leyes de migración y extranjería vigentes. De acuerdo al Censo de 2007 en El Salvador existían 37,820 extranjeros registrados, de los cuales 26,731 son oriundos de alguno de los países de Centroamérica; los hondureños son el mayor grupo seguido por los guatemaltecos. Todo ello, sin considerar el subregistro que nos indicaría que son mucho más, según el estudio Flujos migratorios laborales regionales, realizado en 2010 por el Sistema de Integración Centroamericana (SICA). Se calcula que en nuestro país hay unos $250 \mathrm{mil}$ nicaragüenses ${ }^{55}$, la inmensa mayoría de los cuales tienen la condición de extranjeros "indocumentados".

Con todo esto quiero decir que la cuestión de extranjería no sólo es un estado jurídico, sino que conlleva connotaciones étnicas, raciales y sobre todo vínculos económicos y eso es lo que llevan implícitas las dos leyes antes mencionadas. Son discriminatorias de grupos hondureños y nicaragüenses, entre otros grupos (p.e. ecuatorianos y colombianos). ¿Dónde quedaron los derechos de extranjería en estas dos leyes?

Para subsanar las deficiencias en materia migratoria y de extranjería que afectan directamente a los trabajadores migrantes, el país firmó la Convención internacional sobre la protección de los derechos de todos los trabajadores migratorios y sus familias (conocida como la "Convención del 90"). Este instrumento fue aprobado por la ONU el 18 de diciembre de 1990, nuestro país la ratificó el 14 de marzo de 2003.

La Convención tiene por objeto establecer normas mínimas que los Estados deben aplicar a los trabajadores migratorios y a sus familiares, independientemente de su condición migratoria. El problema de esta Convención así como el de las 
dos leyes antes mencionadas es que parten del supuesto del principio jurídico de la soberanía del Estado para determinar al extranjero y otorgarle derechos exigibles dentro de su territorio.

Si bien El Salvador ha suscrito la Convención del 90 asimismo ha firmado, pero no ha ratificado, los otros dos convenios complementarios: el Convenio de la Organización Internacional del Trabajo (OIT) de 1949 relativo a los trabajadores migrantes (revisado) (núm. 97) conocido como "C 97"; y el Convenio de la OIT de 1975 sobre las migraciones en condiciones abusivas y la promoción de la igualdad de oportunidades y de trato de los trabajadores migrantes (Disposicio- nes complementarias) (núm. 143). Conocido como "C143"56. Según la ONU los tres documentos en conjunto son la espina dorsal en la protección de los derechos humanos de los trabajadores en una época de globalización y en la que el derecho al trabajo implica moverse del propio lugar de origen y caer en la categoría de extranjero ${ }^{57}$.

Un problema que sale a luz es la ambigüedad de los Estados como el nuestro: firmamos documentos internacionales de protección a migrantes para que beneficien a nuestros emigrantes pero no queremos reconocer ese mismo trato al "Otro" cuando pasa o se queda en el país. La hospitalidad y la reciprocidad la hemos olvidado.

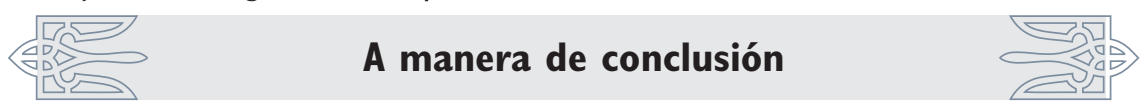

Al final del recorrido que hemos hecho nos quedan más preguntas que respuestas ante la problemática génesis y evolución de las leyes de extranjería y migración para el caso salvadoreño.

Realmente el desafío para los políticos de hoy consiste en recuperar ese espíritu político de unidad de la región centroamericana y plasmarlo en las leyes relativas a los derechos y deberes de los extranjeros.

El desafío de la globalización nos presenta un dilema ético y jurídico a la hora de legislar: o creamos leyes que coadyuven a la unidad política de la región o creamos leyes que fragmenten más a Centroamérica. Igual nos globalizamos con la diferencia que en el primer caso las leyes de migración son favorables para la defensa de los derechos humanos de los migrantes. Por el contrario, en el segundo caso, las leyes de migración son un obstáculo para el desarrollo humano de la región al poner trabas y más trabas para los que buscan hacer su vida en un lugar distinto de donde nacieron.

La lección que nos deja la legislación para extranjeros y sobre 
las migraciones del siglo XIX es que pueden hacerse leyes que sin menoscabo de la nación, ni de la nacionalidad, ni de la soberanía nacional igual ofrecieron la capacidad de regular los flujos migratorios.

Hoy, en pleno siglo XXI, no estamos proponiendo volver al pasado sino recuperar ese espíritu de aquellos legisladores, cuyas leyes tenían en el centro de ellas a la persona humana, lo que incluye favorecer su derecho a moverse libremente siempre y cuando esto sirva para construir el bien común tanto en su persona como en lo social.

Las primeras leyes relativas a los extranjeros dictadas en el siglo XIX creyeron y le apostaron a recibir a los extranjeros europeos en un contexto en el que la región se concebía a sí misma con una sola nacionalidad: la centroamericana.

Para el siglo XX los políticos y las élites dominantes tenían claro que el elemento extranjero, más que ayudar a desarrollar la región y sobre todo El Salvador, intervino a obstaculizar el crecimiento del país. Las leyes se endurecieron y fueron construyendo un país cerrado al Otro y manteniendo un discurso ideologizado que clasifica al extranjero como turista, o sea, aquel extranjero con alto poder adquisitivo que viene por recreación personal; en el otro extremo, clasifica al extranjero como "trabajador" que debe someterse a las reglas establecidas para ello. En ambos casos, su condición de persona con derechos inalienables, independientemente de su condición migratoria, queda en duda y más bien queda subordinada a su clasificación jurídica en cualquiera de las dos categorías antes mencionadas: el extranjero como persona solamente se le reconocen derechos como turista o como trabajador, lo cual tampoco es verdadero. Basta ver las constantes violaciones a los derechos laborales de los trabajadores extranjeros para constatar esta afirmación. Cualquier otra condición jurídica es la no-persona, como lo hemos indicado más arriba.

Es obvio que la carga negativa que adquiere el concepto de "extranjero" entre 1933 y 1958 es producto de una xenofobia ideológica más que étnica. De acuerdo a Knut Walter nuestro país fue inundado por corrientes poderosísimas provenientes del exterior entre ellas:

- El nacionalismo de la revolución mexicana

- El internacionalismo de la revolución bolchevique

- Las notas de prensa que daban cuenta de la lucha del ejército sandinista que mantuvo un combate contra la Infantería de Marina de los EE.UU entre 1927 y $1932^{58}$.

- La crisis económica de 1929. 
La ley de migración de alguna manera sirvió para proteger los intereses de los comerciantes ya establecidos, poniendo más trabas a los nuevos ciudadanos que quisieran venir a instalarse en estas tierras.

A partir de los años setentas del siglo XX el país sufre graves conflictos armados que empujan a la población a refugiarse en países vecinos y sobre todo en los EE.UU. La guerra contra Honduras en 1969 agudizó las relaciones sociales entre los dos países, ya que tanto los salvadoreños en Honduras como los hondureños en El Salvador sufrieron discriminación racial tal como lo ha documentado Carlos Pérez Pineda ${ }^{59}$.

Cada sociedad toma los derroteros que mejor le parecen, conforme a esos ideales se toman decisiones políticas y muchas de esas decisiones terminan siendo concretizadas en leyes. El discurso jurídico a través de las leyes sobre extranjeros en el siglo XIX parece más justo para la realidad de Centroamérica actual que el discurso jurídico sobre el extranjero de hoy en día.

La sociedad de 1886 optó por hacer de Centroamérica un asilo sagrado para el extranjero, eso lo convirtió en política, en acciones; la sociedad de 1933 optó por la intolerancia ideológica y esa opción la tradujo en acciones políticas concretas; la sociedad de 1958 optó por acabar con el liberalismo político y optó claramente por una política económica que subsumió la unidad política a la unidad económica de Centroamérica. Eso se tradujo en acciones políticas que ahora impactan la región. Aquí inicia la política de seguridad de las fronteras. $Y$ esta sociedad de siglo XXI ¿qué opciones, qué posibilidades tiene ante sí? ¿Por cuáles va a optar?

\section{Bibliografía}

- Hopenhayn M., Discriminación étnico-racial y xenofobia en América Latina y el Caribe. CEPAL. Santiago de Chile. 2001.

- Cuenin, X "Representar e imaginar Centroamérica en el siglo XIX", Boletín AFEHC N46, publicado el 04 septiembre 2010.

- Historización del concepto de propiedad como principio de desideologización. Estudios Centroamericanos (ECA) 335-336, 1976.

- La historización del bien común y de los derechos humanos en una sociedad dividida. Torres, E y Trinidad, S (Coord.) Capitalismo y anti-vida, Educa, San José, 1978. Págs.81-94.

- La historización de los derechos humanos desde los pueblos oprimidos y las mayorías populares. Estudios Centroamericanos (ECA) 502, 1990. Págs. 589-96.

- Osorio, M. Diccionario de Ciencias Jurídicas Políticas y Sociales ver- 
sión electrónica, disponible en enj.org/portal/index.php?option=com_ docman\&task

- Román Reyes (Dir.): Diccionario Crítico de Ciencias Sociales. Terminología Científico-Social, Tomo 1/2/3/4, Ed. Plaza y Valdés, Madrid-México 2009.

- Instituto Nacional de Estadística, Geografía e Informática (INEGI) Los extranjeros en México. INEGI, México, 2006.

- Alberdi, J.B. Bases y Puntos de Partida para la Organización Política de la República Argentina. Edición original de 1852.

- Mayer, J. M: Las bases de Alberdi. Edición crítica con una noticia preliminar. Buenos Aires, Sudamericana, 1979.

- Valdés Valle, R. Masones, Liberales y Ultramontanos salvadoreños: debate político y constitucional en algunas publicaciones impresas, durante la etapa final del proceso de secularización del Estado salvadoreño (18851886). Tesis para optar al grado de Doctor en Filosofía Iberoamericana por la UCA, San Salvador, 2010.

- Constitución de la República Federal de Centroamérica del 22 de noviembre de 1824.

- Ley de Extranjería de 1886.

- Carlos Loucel, «Negros y mulatos de San Geronymo Nejapa en el siglo XVIII», Boletín AFEHC №21, publicado el 04 junio 2006.

- Jorge Alberto Amaya, "Los negros ingleses o creoles de Honduras: Etnohistoria, racismo, nacionalismo y construcción de imaginarios nacionales excluyentes en Honduras», Boletín AFEHC Nº13, publicado el 04 octubre 2005.

- Jorge Victoria Ojeda, «Los negros auxiliares de España en Centroamérica», Boletín AFEHC N²1, publicado el 04 junio 2006.

- Rina Cáceres: Negros, mulatos, esclavos y libertos en la Costa Rica del sig/o XVII, Editorial Instituto Panamericano de Geografía e Historia, México, 2000.

- Barón Castro, R. La población de El Salvador. Concultura, San Salvador, 2002.

- Bernal López, C.G. (Comp.) Poder, actores sociales y conflictividad. El Salvador, 1786-1972. DNI, SEC, San Salvador, 2011.

- Dirección General de Estadísticas Anuario Estadístico 1937. Tipografía La Unión, San Salvador, 1938. 
- Gallardo, M. A. Cuatro Constituciones federales de Centroamérica y las Constituciones políticas de El Salvador.

- Anino, A y Guerra, F. X (Coord.) Inventado la nación. Iberoamérica. Siglo XIX FCE, México, 2003.

- González Torres, J. Del "Ciudadano Católico» al "Ciudadano Laico». La escuela pública primaria y la formación de los futuros ciudadanos. El Salvador 1824-1890. Tesis para optar al grado de Doctor en Filosofía Iberoamericana por la Uca, San Salvador, 2012.

- López Bernal, C.G "Inventando tradiciones y héroes nacionales: El Salvador (1858-1930)", Boletín AFEHC №19, publicado el 04 abril 2006.

- Ellacuría, I. Filosofía de la realidad histórica. Uca ed. San Salvador, 1999.

- Silveira Gorski H. (Ed) Identidades comunitarias y democracia, Ed. Trotta, Madrid, 2001.

- Ley de Migración de 1933. Diario Oficial del 21 de junio de 1933. Tomo 114, número 139.

- Hinkelammert. Sacrificios humanos y sociedad occidental. Dei, San José, 1991. Pág. 144.

- Wilson, E. A.: La crisis de la integración nacional en El Salvador 19191935. DPI-Concultura, San Salvador, 2004.

- Bernal López, C. G. Las masas, la matanza y el martinato en El Salvador UCA Editores, San Salvador, 2007.

- Oliva Mancía M. D. Ciudadanía e higienismo social en El Salvador, 1880-1932. Tesis preparada para la Facultad de Postgrados de la UCA para optar al Grado de Doctor en Filosofía Iberoamericana. San Salvador, Mayo 2011.

- Magaña Granados, A (Ed.): El Salvador: la República. Fomento cultural, Banco Agrícola, San Salvador, 2000.

- Barón Castro, R. La población de El Salvador. Concultura, San Salvador, 2002.

- Marta Elena Casaus Arzú "El vitalismo teosófico como discurso alternativo de las élites intelectuales centroamericanas en las décadas de 1920 y 1930. Principales difusores: Porfirio Barba Jacob, Carlos Wyld Ospina y Alberto Masferrer" REHMLAC Vol. 3, № 1, Mayo 2011-Noviembre 2011. 
- Lara Martínez R. Teosofía de la liberación contribución académica publicada el 13 mayo de 2011 en diario digital ContrACultura en línea http://www.contracultura.com.sv/teosofia-de-la-liberacion

- Barberena, S. Descripción geográfica y estadística de la República de EI Salvador. Imprenta Nacional, San Salvador, 1892.

- Carta de la Organización de Estados Centroamericanos (ODECA) disponible en http://www.sice.oas.org/Trade/sica/PDF/CartaODECA62.pdf

- SICA: Protocolo de Tegucigalpa a la Carta de la Organización de Estados Centroamericanos (ODECA) firmado por Guatemala, Honduras, Nicaragua, El Salvador, Costa Rica y Panamá 13 de diciembre de 1991.

- Ellacuría, I. "Historización del bien común y de los derechos humanos en una sociedad dividida" en Escritos filosóficos vol. III. Uca Ed. San Salvador, 2001.

- Maguid, A., Los esfuerzos de las poblaciones: Las migraciones en Centroamérica, San José. 1999.

- Acuña González, G. Flujos migratorios laborales intrarregionales: situación actual, retos y oportunidades en Centroamérica y República Dominicana. Informe regional. OIM, OIT, MTSS, CECC SICA, OCLAD, Red de Observatorios del Mercado Laboral, AECID. San José, 2011.

- OIM Políticas públicas sobre migración laboral. OIM, México, 2010.

- Organización de la Naciones Unidas Migración internacional y desarroIlo Informe del Secretario General, 2010.

- Samour H. Voluntad de liberación, Uca Ed. San Salvador.

- AA.VV El salvador: historia mínima. SEC. San Salvador, 2011.

- Ellacuría, I. Filosofía de la realidad histórica. Uca Ed. San Salvador, 1999. 
1 Cf. Hopenhayn M., Discriminación étnico-racial y xenofobia en América Latina y el Caribe. CEPAL. Santiago de Chile. 2001. Pág. 10 en adelante.

2 Cuenin, X "Representar e imaginar Centroamérica en el siglo XIX", Boletín AFEHC $N^{\circ} 46$, publicado el 04 septiembre 2010. disponible en: http:// afehc-historia-centroamericana.org/ index.php?action=fi_aff\&id $=2496$

3 El método de historización de los conceptos en Ellacuría lo podemos ubicar en los siguientes textos:

-"Historización del concepto de propiedad como principio de desideologización". Estudios Centroamericanos (ECA) 335-336, 1976. Págs. 425-50

-"La historización del bien común y de los derechos humanos en una sociedad dividida". Torres, E y Trinidad, S (Coord.) Capitalismo y anti-vida, Educa, San José, 1978. Págs.81-94.

-"La historización de los derechos humanos desde los pueblos oprimidos y las mayorías populares". Estudios Centroamericanos (ECA) 502, 1990. Págs. 589-96.

En estos ensayos se supone que Ellacuría traza las grandes líneas o el esquema fundamental que sustentaría un "método" filosófico para ser aplicado a cualquier concepto, siempre y cuando se quiera problematizar la ideología dominante que está llena de "conceptos abstractos y universales".

4 En lineamiento sintético, régimen jurídico del que disfruta o al que está sometido el extranjero, el que no posee la nacionalidad del territorio independiente en que se encuentra.

5 "Por extranjero entendemos la calidad y condición que por las leyes corresponden al extranjero residente en un país, mientras no está naturalizado en él. | Sistema o conjunto de normas, reguladoras de la condición, los actos e intereses de los extranjeros" Cf. Osorio, M. Diccionario de Ciencias Jurídicas Políticas y Sociales versión electrónica, disponible en enj.org/portal/index. php?option $=$ com_docman\&task

6 Cf. Oliván López, F. “El extranjero y lo nacional". En Román Reyes (Dir.): Diccionario Crítico de Ciencias Sociales. Terminología Científico-Social, Tomo 1/2/3/4, Ed. Plaza y Valdés, Madrid-México 2009. http://www.ucm.es/info/eurotheo/ diccionario/E/extranjero_nacional.htm

7 Cf. Instituto Nacional de Estadística, Geografía e Informática (INEGI) Los extranjeros en México. INEGI, México, 2006. Pág. 3. En línea: http://www. inegi.gob.mx/prod_serv/contenidos/ espanol/bvinegi/productos/estudios/ sociodemografico/ext_en_mex/extraen_mex.pdf

8 Alberdi, J.B. Bases y Puntos de Partida para la Organización Política de la República Argentina. Edición original de 1852. $\mathrm{n}^{\circ} \mathrm{XXX}$. Cf. Mayer, J. M: Las bases de Alberdi. Edición crítica con una noticia preliminar. Buenos Aires, Sudamericana, 1979.

9 Alberdi, J.B. Bases...Op. Cit $\mathrm{N}^{\circ} \mathrm{XXX}$

10 Cf. Alberdi, J.B. Prólogo. Bases...Op. Cit.

11 Ibíd.

12 "Teniendo en cuenta todos estos elementos, me he permitido calificar el proceso de transformación del Estado salvadoreño que arranca desde 1871 y culmina en 1886 como un proceso de "secularización". Valdés Valle, R. Masones, Liberales y Ultramontanos salvadoreños: debate politico y constitucional en algunas publicaciones impresas, durante la etapa fi- 
nal del proceso de secularización del Estado salvadoreño (1885-1886). Tesis preparada para la Facultad de Postgrados para optar al grado de Doctor en Filosofía Iberoamericana por la UCA, San Salvador, 2010. Pág. 12. Disponible en sitio web del Departamento de Filosofía en http://www.uca.edu.sv/filosofia/ admin/files/1260825405.pdf

13 Constitución de la República Federal de Centroamérica del 22 de noviembre de 1824. Disponible en http://www. bibliojuridica.org/libros/4/1541/9.pdf

14 Ver Arts. 26 y 36 de Ley de Extranjería de 1886.

15 Algunas fuentes documentales que he consultado para sostener esta afirmación: Carlos Loucel, «Negros y mulatos de San Geronymo Nejapa en el siglo XVIII», Boletín AFEHC N²1, publicado el 04 junio 2006, disponible en: http://afehc-historia-centroamericana. org/index.php?action=fi_aff\&id=376; Jorge Alberto Amaya, «Los negros ingleses o creoles de Honduras: Etnohistoria, racismo, nacionalismo y construcción de imaginarios nacionales excluyentes en Honduras», Boletín AFEHC N¹3, publicado el 04 octubre 2005, disponible en: http://afehchistoria-centroamericana.org/index. php?action=fi_aff\&id $=377$; Jorge Victoria Ojeda, "Los negros auxiliares de España en Centroamérica», Boletín AFEHC $\mathrm{N}^{\circ} 21$, publicado el 04 junio 2006, disponible en: http:// afehc-historia-centroamericana.org/ index.php?action $=$ fi_aff\&id $=375$; Rina Cáceres: Negros, mulatos, esclavos y libertos en la Costa Rica del siglo XVII, Editorial Instituto Panamericano de Geografía e Historia, México, 2000.

16 Barón Castro, R. La población de El Salvador. Concultura, San Salvador, 2002. Pág. 387.
17 Cf. Prud'homme, O. "De Belén a El Salvador: migración de cristiano-palestinos y sus prácticas comerciales como estrategia de inserción (1886-1918)" en Bernal López, C.G. (Comp.) Poder, actores sociales y conflictividad. El Salvador, 1786-1972. DNI, SEC, San Salvador, 2011. Pág. 249.

18 Fue hasta 1911 que se publicó el Primer Anuario Estadístico, luego desde 1912 hasta 1985 se logra mantener la publicación de los Anuarios en forma continua, con variaciones de los temas y en el formato de las ediciones. En la Biblioteca Florentino Idoate de la Universidad Centroamericana José Simeón Cañas se halla disponible el Anuario Estadístico de 1916-1959 editado por la Dirección General de Estadísticas. Al revisarlos, nos dimos cuenta que está incompleto.

19 Dirección General de Estadísticas Anuario Estadístico 1937. Tipografía La Unión, San Salvador, 1938. Pág. 11.

20 Gallardo, M. A. Cuatro Constituciones federales de Centroamérica y las Constituciones politicas de El Salvador. Op. Cit. Pág. 220.

21 Consultar el interesante trabajo de Bustamante, G. El Derecho del Trabajo y los Inmigrantes en El Salvador. Tesis para optar al título de doctor en jurisprudencia y ciencias sociales por la Universidad de El Salvador 1978. disponible en http://www.csj.gob.sv/BVirtual.nsf/3 db6532d39e032fd06256b3e006d8a73/ 132dc752b3bead6006256b3e00747a30 ?OpenDocument

22 Gallardo, M. A. Cuatro Constituciones federales de Centroamérica y las Constituciones politicas de El Salvador. Tipografía La Unión, San Salvador, 1945. Pág. 234.

23 Guerra, F. X "Las mutaciones de la identidad en la América hispana" en Inventado la nación. Iberoamérica. Siglo XIX (Anino, A y Guerra, F. X Coord.) FCE, 
México, 2003. Pág. 187. Las cursivas son mías.

24 González Torres, J. Del «Ciudadano Católico» al "Ciudadano Laico». La escuela pública primaria y la formación de los futuros ciudadanos. El Salvador 1824-1890. Págs. 43-44. Consultada en sitio web del Dpto. de Filosofía de la UCA en http://www.uca.edu.sv/filosofia/ad$\mathrm{min} /$ files/1341957152.pdf

25 Valdés Valle. R "Masones, Liberales y Ultramontanos salvadoreños ..." Op. Cit. Pág 56. Cursivas mías.

26 "Unos agricultores", La República (207), Viernes 23 de Octubre de 1885, p. 2.

27 La investigación doctoral de Valdés Valle (Op. Cit.) originalmente incluía siete capítulos, cuando presentó su informe final únicamente incluyó cuatro y dejó por fuera los otros tres capítulos. Le agradezco que me compartiera esos capítulos inéditos para discutirlos en mi estudio.

28 López Bernal, C.G "Inventando tradiciones y héroes nacionales: El Salvador (1858-1930)", Boletín AFEHC $\mathrm{N}^{\circ} 19$, publicado el 04 abril 2006, disponible en: http://afehchistoria-centroamericana.org/index. php?action $=$ fi_aff\&id $=373$

29 Ellacuría, I. Filosofía de la realidad histórica. UCA ed. San Salvador, 1999. Pág. 528.

30 Tanto la "persona" como la "no-persona" se construyen jurídicamente: la persona sólo puede existir socialmente como persona jurídico-política, o bien como sistema de derechos y deberes (Kelsen), o bien como sujetos de un ordenamiento político (Schmitt.) Tanto para Kelsen como para Schmitt la "persona" y la no-persona" está determinada por la posición en el interior o el exterior de un ordenamiento jurídico concreto. Cf. Del Lago A. "Persona y no-persona" pág. 134-135 en Silveira Gorski H. (Ed) Identidades comunitarias y democracia, Ed. Trotta, Madrid, 2001.

31 Ching, E. "El levantamiento de 1932" en AA.VV El Salvador: historia mínima. DNI-SEC. San Salvador, 2011. Pág. 68.

32 Ver Artículo 10 de la Ley de Migración de 1933. Diario Oficial del 21 de junio de 1933. Tomo 114, número 139.

33 Cf. Escalante Arce, P. Daura Molina, A. Sobres moros y cristianos y otros arabismos en El Salvador. San Salvador, Agencia Española de Cooperación Internacional, 2001.

34 Según Hinkelammert: "Este antisemitismo es a la vez anti-socialismo, porque identifica lo judío con lo socialista. Por eso, en los años veinte el Occidente burgués consideraba al bolchevismo como "bolchevismo judío". La proyección del judío como monstruo era a la vez parte de la proyección del socialismo como monstruo, y el exterminio de los judíos era para los nazis míticamente el exterminio del socialismo en sus raíces. Sacrificios humanos y sociedad occidental. Dei, San José, 1991. Pág. 144.

35 Cf. Prud'homme, O. De Belén a El Salvador: migración de cristiano-palestinos y sus prácticas comerciales como estrategia de inserción (1886-1918) en Bernal López, C.G. (Comp.) Poder, actores sociales y conflictividad. El Salvador, 1786-1972. DNI, SEC, San Salvador, 2011. Pág. 252

36 Ibíd. Pág. 253.

37 Cf.Ibíd. Pág. 250. Cf también Wilson, E. A.: La crisis de la integración nacional en El Salvador 1919-1935. DPI-Concultura, San Salvador, 2004. Pág. 23.

38 Wilson, E. A.: La crisis de la integración nacional en El Salvador 1919-1935. DPIConcultura, San Salvador, 2004. Pág. 21. 
39 Ley de Migración de 1933. Diario Oficial del 21 de junio de 1933. Tomo 114, número 139.

40 Bernal López, C. G: "Lecturas desde la derecha y la izquierda sobre el levantamiento de 1932: Implicaciones políticoculturales" en Las masas, la matanza y el martinato en El Salvador (Bernal López, C. G. Comp.)UCA Editores, San Salvador, 2007. Pág. 193. Cursivas nuestras.

41 Oliva Mancía M. D. Ciudadanía e bigienismo social en El Salvador, 1880-1932. Tesis preparada para la Facultad de Postgrados de la UCA para optar al Grado de Doctor en Filosofía Iberoamericana. San Salvador, Mayo 2011. Págs. 84-85.

42 Cf: López Bernal, C.G. “Tiempos de liberales y reformas" en Magaña Granados, A (Ed.): El Salvador: la República. Fomento cultural, Banco Agrícola, San Salvador, 2000.

43 Barón Castro, R. La población de El Salvador. Concultura, San Salvador, 2002. Pág. 382.

44 Según Marta Elena Casaus Arzú "En El Salvador la difusión de la teosofía fue tan grande que hubo incluso un presidente teósofo, el General Maximiliano Martínez Hernández, quien impuso la teosofía a todo el gobierno y desarrolló experimentos agrícolas basados en esta ideología. Se hacía llamar además "Maestro", leía cartas astrales y "los textos escolares estaban sazonados de pizcas de budismo y teosofía”. Uno de sus primeros aliados, luego enemigo acérrimo, fue Alberto Masferrer" en "El vitalismo teosófico como discurso alternativo de las élites intelectuales centroamericanas en las décadas de 1920 y 1930. Principales difusores: Porfirio Barba Jacob, Carlos Wyld Ospina y Alberto Masferrer", REHMLAC Vol. 3, No 1, Mayo 2011-Noviembre 2011. Pág. 91. En línea http://www.latindex. ucr.ac.cr/rehmlac-3-/rehmlac-3-1-06. pdf

45 Según Rafael Lara Martínez: "A la imagen actual de Martínez como "dictador despiadado y autor de la matanza", sus contemporáneos lo describen como "distinguido hombre de letras y entusiasta apreciador de las obras que llevan en sí la idea de ennoblecer el país por medio del espíritu" (Boletín, Nos. 9-10, julio/agosto/1933: 3Boletín, Nos. 9-10, julio-agosto de 1933: 3) Lo respalda la integridad de la ciudad letrada y teósofos autónomos como Salarrué. La reseña oficial del evento al cual asiste "numeroso público amante de la cultura espiritual" la realiza La República, periódico que reconfirma vínculo entre mandatario, intelectuales y grupos masferrerianos que impulsan participación de la mujer (Boletín, Nos. 9-10, julio/agosto/1933: 3; Boletín, Nos. 9-10, julio-agosto de 1933: 3)" Y prosigue Lara Martínez:

"Hacia finales de 1933, existe evidencia suficiente para asegurar que Martínez recibe el apoyo incondicional del Grupo Masferrer y de la mayoría de intelectuales y artistas salvadoreños, ahora consagrados como clásicos. Un nuevo proyecto de nación que valora la herencia indígena por medio de la plástica, literatura y danzas autóctonas se halla a la obra. Si a esta "política de la cultura" se agrega la planificación de una reforma agraria, de vivienda barata para "proletarios", promoción del turismo, al igual que la educación "popular" y "de la tropa", no resultaría contradictorio que a Martínez el Suplemento del Diario Oficial lo califique de "masferreriano". El calificativo "masferreriano" lo legitima una amplia "reforma educativa" la cual se concentra en diseminar una cultura nacional por la lecto-escritura, alfabetización, bibliotecas populares, escuelas rurales 
de carácter práctico, cursos de extensión cultural, pláticas informativas para "proletarios" o "clase laborante", uso de la radio para fines pedagógicos y culturales, mejoramiento de escuelas normales, etc. La "obra de aliento" del "Supremo Gobierno" elevaría la condición escolar de "las clases pobres, trabajadoras, que entre nosotros representan la gran mayoría aborigen [indígena]" (La República, Año I, No. 310, 12 de diciembre de 1933). Estos "asomos de evolución cultural" brotarían de una "nacionalización de la escuela" masferreriana. (La República, No. 255, 7 de octubre de 1933.) en Teosofía de la liberación contribución académica publicada el 13 mayo de 2011 en diario digital ContrACultura en línea http:// www.contracultura.com.sv/teosofia-dela-liberacion

46 Barberena, S. Descripción geográfica y estadística de la República de El Salvador. Imprenta Nacional, San Salvador, 1892. Pág. 90.

47 La Carta constitutiva de la ODECA firmada en 1951 fue sustituida por una nueva Carta firmada en Panamá el 12 de diciembre de 1962 pero que conserva su nombre de Carta de San Salvador. La razón de su abolición fue porque enfatizaba la unión política y lo que CEPAL deseaba era la unión económica de la región. Esa integración se dio en la VII reunión del CCE en Managua el 13 de diciembre de 1960, El Salvador, Guatemala, Honduras y Nicaragua firmaron el Tratado General de la Integración económica centroamericana (TGIE) y el Convenio constitutivo del Banco Centroamericano de Integración Económica (BCIE).

48 Carta de la Organización de Estados Centroamericanos (ODECA) disponible en http://www.sice.oas.org/Trade/ sica/PDF/CartaODECA62.pdf
49 SICA: Protocolo de Tegucigalpa a la Carta de la Organización de Estados Centroamericanos (ODECA) firmado por Guatemala, Honduras, Nicaragua, El Salvador, Costa Rica y Panamá 13 de diciembre de 1991. Disponible en http://www. sica.int/busqueda/centro $\% 20 \mathrm{de} \% 20$ documentaci $\% \mathrm{C} 3 \% \mathrm{~B} 3$ n. aspx?IdItem $=3$ 72\&IdCat $=8 \& I d E n t=401$ Cursivas son mías.

50 Ibíd.

51 Ellacuría, I. "Historización del bien común y de los derechos humanos en una sociedad dividida" en Escritos filosóficos vol. III. Uca Ed. San Salvador, 2001. Pág. 219.

52 Cf. Maguid, A., Los esfuerzos de las poblaciones: Las migraciones en Centroamérica, San José. 1999.

53 De acuerdo al Censo de 2010 la cifra aumentó en un $152 \%$ alcanzando el número de 1.6 millones de salvadoreños. Cf. <www.census.gov/>

54 Acuña González, G. Flujos migratorios laborales intrarregionales: situación actual, retos y oportunidades en Centroamérica y República Dominicana. Informe regional. OIM, OIT, MTSS, CECC SICA, OCLAD, Red de Observatorios del Mercado Laboral, AECID. San José, 2011. Págs. 27-29 consultado en http://www. iom.int/files/live/sites/iom/files / $\mathrm{pbn/docs/Informe-Costa-Rica-Flujos-}$ Migratorios-Laborales-Intrarregi.pdf

55 Ibíd.

56 "Los convenios 97 y 143 establecen medidas de protección para los trabajadores migrantes y derechos laborales en caso de cese de empleo, remuneración, seguridad social, salarios y prestaciones" Ver OIM Políticas públicas sobre migración laboral. OIM, México, 2010. Pág. 47. 
57 Organización de la Naciones Unidas Migración internacional y desarrollo Informe del Secretario General, 2010. Disponible en http://daccess-dds-ny.un.org/ doc/UNDOC/GEN/N10/470/07/ PDF/N1047007.pdf?
58 Cf. Wilson, E. A. La crisis de la integración...Op. Cit. Pág. 11.

59 La guerra con Honduras: ¿nacionalismo o falta de visión? (1969) en AA.VV El Salvador: historia minima. SEC. San Salvador, 2011. 